\title{
Performance of Chia on Different Sowing Dates: Characteristics of Growth Rate, Leaf Area Index, Shoot Dry Matter Partitioning and Grain Yield
}

\author{
Patrícia Carine Hüller Goergen ${ }^{1}$, Isabel Lago ${ }^{2}$, Angelica Durigon ${ }^{2}$, Gabriel Felipe Maboni Roth ${ }^{3}$, \\ Lúcio Gabriel Scheffel ${ }^{4} \&$ Taís $\mathrm{Slim}^{3}$ \\ ${ }^{1}$ Postgraduate Program in Agronomy, Federal University of Santa Maria, Santa Maria, Brazil \\ ${ }^{2}$ Professor in Department of Crop Science, Federal University of Santa Maria, Santa Maria, Brazil \\ ${ }^{3}$ Graduating in Agronomy, Federal University of Santa Maria, Santa Maria, Brazil \\ ${ }^{4}$ Agronomist Engineer, Federal University of Santa Maria, Santa Maria, Brazil \\ Correspondence: Patrícia Carine Hüller Goergen, Postgraduate Program in Agronomy, Federal University of \\ Santa Maria, Avenida Roraima, $n^{\circ}$ 1000, Bairro Camobi, CEP: 97105-900, Santa Maria, RS, Brazil. Tel: \\ 55-991-397-063. E-mail: patygoergen@hotmail.com
}

$\begin{array}{lc}\text { Received: March 26, } 2019 & \text { Accepted: April 30, } 2019 \quad \text { Online Published: June 30, } 2019 \\ \text { doi:10.5539/jas.v11n9p252 } & \text { URL: https://doi.org/10.5539/jas.v11n9p252 }\end{array}$

\begin{abstract}
The objective of this study was to comparatively determine the characteristics of growth rate, leaf area index, shoot dry mass partitioning and grain yield of chia plants (Salvia hispanica L.) on different sowing dates. A field experiment was conducted in the crop year of 2016/2017 in five sowing dates $(09 / 22 / 16,10 / 28 / 16,01 / 03 / 17$, 02/08/17 and 03/24/17) with a randomized complete block design and four replicates. Plant growth was determined through field samplings to determine the dry matter mass and leaf area performed every 15 days. The following physiological indexes were calculated: relative growth rate, absolute growth rate, net assimilation rate, leaf area ratio, specific leaf area and leaf mass ratio. To weekly evaluate plant height, ten plants per plot were marked after emergence, and the final height was considered when plants reached physiological maturity. A useful area of $2.10 \mathrm{~m}^{2}$ per plot was collected for evaluating grain yield. The physiological indexes indicated that at earlier sowing dates there is a greater plant growth, either in shoot dry matter mass, height and leaf area index. The leaf area index of branches is progressively increased with plant development and contributes significantly to total leaf area index of chia plants in all studied sowing dates. The main stem represents between 60 and $70 \%$ of the shoot dry matter accumulated in the early sowing dates, and between 40 and 50\% in late sowing. The best sowing date in terms of grain yield is 01/03/17.
\end{abstract}

Keywords: Salvia hispanica L., sowing season, dry mass, growth analysis

\section{Introduction}

Plant growth can be defined as the irreversible increase in some of its physical dimensions followed by a combination of cell division and expansion (Benincasa, 2004). The growth analysis is one of the first steps for determining the primary production of a crop. This methodology aims to follow the dynamics of the photosynthetic production evaluated through the accumulation of dry matter mass over time, what is not possible with the simple final yield analysis (C. P. Peixoto \& M. F. da S. Peixoto, 2009). The growth analysis requires information gathered through several physiological indexes, with the most used ones being the relative growth rate, the absolute growth rate, the net assimilation rate, the leaf area index, the specific leaf area, the leaf area ratio and the leaf mass ratio. These variables are directly related to the amount of dry matter mass contained in the whole plant and in its parts (Benincasa, 2004). The final plant height is also a measure of the vegetative growth that supports the evaluation of the final plant growth and the definition of better growing conditions (Zanon et al., 2016).

Growth indexes indicate the capacity of the plant assimilatory system to synthesize and allocate organic matter to the several plant organs (leaves, stems, roots and inflorescences) which depend on the photosynthesis, 
respiration and translocation of photoassimilates from the carbon fixation sites to the use and storage sites (Benincasa, 2004).

When a species is introduced in a region, studies must be carried out to indicate if it will be adapted to the local conditions. In this context, the growth analysis can be used to evaluate the ecological adaptation of plants to new environments, better sowing dates, and the effects of management systems, besides the evaluation of the productive capacity of the crop (Antoniazzi \& Deschamps, 2006; Zanon et al., 2016, 2015a).

Chia (Salvia hispanica L.), of Lamiaceae family, is originated from the region that extends from central-western Mexico to northern Guatemala (Migliavacca et al., 2014). In Brazil, the cultivation of this species is still not very expressive and there is a lack of information regarding the growth, phenology, growing season, nutritional requirements and management strategies for a better use of the edaphoclimatic characteristics of each region. Despite this lack of information, farmers of the western region of Paraná State and the northwest region of Rio Grande do Sul State started to invest in chia cultivation in the last agricultural years and reached good results.

Climate-related ecological factors such as photoperiod and air temperature vary according to the seasons and may interfere with growth, assimilation partition and yield of chia plants. Chia is considered a short-day species (Jamboonsri et al., 2012), and based on the responses of other short-day crops, it is possible to infer that there is variation in the responses of the plants sown in different dates due to the climatic conditions to which they are exposed. Thus, studies on the growth response of chia plants sown on different dates are fundamental to understand the influence of the environment on crop growth and, consequently, on grain yield. No studies were found in the literature reporting growth and yield of chia sown on different dates in the southern region of Brazil, which was an incentive to this work. In addition, it can be considered a promising crop to be introduced in crop rotation of the rural property, due to the good quality of the straw. It also represents an excellent alternative for income generation, due to the high grain value, and assisting the diversification of the agricultural production in the rural properties. The objective of this study was to comparatively determine the characteristics of growth rate, leaf area index, shoot dry mass partitioning and grain yield of chia plants on different sowing dates.

\section{Material and Methods}

A field experiment was conducted in the crop year of 2016/2017 in the experimental area in Santa Maria (latitude: $29^{\circ} 43^{\prime} \mathrm{S}$, longitude: $53^{\circ} 43^{\prime} \mathrm{W}$, and altitude: $95 \mathrm{~m}$ ). The region climate is a Cfa humid subtropical type without a defined dry season and hot summers, according to the Köppen classification (Alvares et al., 2013). The soil in Santa Maria is a transition between a Typic Hapludalf soil and a Rhodic Paleudalf soil (USDA, 1999).

The experiment was carried out in five sowing dates (09/22/16, 10/28/16, 01/03/17, 02/08/17 and 03/24/17), considered to be early, intermediate and late in relation to the season more suitable for the crop that is October/November (Migliavacca et al., 2014). The experimental design was a randomized complete block design with four replicates. Each plot consisted of five rows measuring $3.00 \mathrm{~m}$, spaced $0.70 \mathrm{~m}$ between them, and corresponding to an experimental unit of $10.50 \mathrm{~m}^{2}$. Only plants of the central lines were evaluated, excluding the border lines.

Management practices, such as soil $\mathrm{pH}$ correction and fertilization, were performed according to soil analysis based on mint (Mentha arvensis), which is from the same family as chia, due to the lack of recommendation for Salvia hispanica. For supplementar irrigation, the Kc of the mint crop was used, since this information was not available for chia, and weed control was performed by weeding.

Seeds of chia were purchased from a seed company located in the municipality of Santa Cruz do Sul, RS. Sowing was done manually in rows with a seeding depth of $0.01 \mathrm{~m}$. After the emergence, the plants were thinned to maintain a distance between plants of 0.05 to $0.06 \mathrm{~m}$ in the sowing line, and to establish an average of 20 plants per linear meter (Migliavacca et al., 2014).

The meteorological data (minimum and maximum daily air temperatures, precipitation, solar radiation and photoperiod) were collected at the meteorological station belonging to the 8th District of Meteorology of the National Institute of Meteorology (DISME/INMET) located at approximately $100 \mathrm{~m}$ of the experimental area.

Plant growth was determined through field samplings. Three plants per plot were randomly collected every 15 days starting at 30 days after emergence to determine the dry matter mass, except for the sowing date of $09 / 22 / 16$, and leaf area $\left(\mathrm{LA}, \mathrm{cm}^{2}\right)$. To obtain the total dry matter and the assimilated partition, plants were cut close to the soil and separated into its parts (stems, leaves and inflorescences) of the main stem and branches. Plant parts were dried out in an oven with a temperature of $65^{\circ} \mathrm{C}$ until constant weight. The dry matter fraction of each part (stems, leaves and inflorescences) was calculated based on the dry matter of each compartment relative to the total shoot dry matter (SDM, g). 
The following physiological indexes were calculated, according to Benincasa (2004): the relative growth rate (RGR), the absolute growth rate (AGR), the net assimilation rate (NAR), the leaf area index (LAI), the leaf area ratio (LAR), the specific leaf area (SLA), and the leaf mass ratio (LMR).

The relative growth rate (RGR, $\mathrm{g} \mathrm{g}^{-1} \mathrm{day}^{-1}$ ) (Equation 1):

$$
R G R=\left(\ln \mathrm{SDM}_{2}-\ln \mathrm{SDM}_{1}\right) /\left(\mathrm{t}_{2}-\mathrm{t}_{1}\right)
$$

where, $\ln$ SDM is the transformed total shoot dry matter mass (g), $t$ is time (day), and 1 and 2 are the consecutive samplings.

The absolute growth rate (AGR, g plant ${ }^{-1}$ day $^{-1}$ ) (Equation 2):

$$
A G R=\left(\mathrm{SDM}_{2}-\mathrm{DM}_{1}\right) /\left(\mathrm{t}_{2}-\mathrm{t}_{1}\right)
$$

where, SDM is the total shoot dry matter mass (g), $\mathrm{t}$ is time (day), and 1 and 2 are the consecutive samplings.

The net assimilation rate (NAR, $\mathrm{mg} \mathrm{cm}^{-2}$ plant $^{-1} \mathrm{day}^{-1}$ ) (Equation 3):

$$
N A R=\left[\left(\mathrm{SDM}_{2}-\mathrm{SDM}_{1}\right) /\left(\mathrm{LA}_{2}-\mathrm{LA}_{1}\right)\right] \cdot\left[\left(\ln \mathrm{LA}_{2}-\ln \mathrm{LA}_{1}\right) /\left(\mathrm{t}_{2}-\mathrm{t}_{1}\right)\right]
$$

where, SDM is the total shoot dry matter mass $(\mathrm{g})$, LA is the leaf area $\left(\mathrm{cm}^{-2}\right), \ln$ LA is the transformed leaf area, $\mathrm{t}$ is time (day), and 1 and 2 are the consecutive samplings.

The length and width of all leaves of the plants were measured to determine the leaf area. The length and width measurements were used to estimate the area of individual leaves through an equation calibrated for chia using 70 leaves: LA $\left(\mathrm{cm}^{2}\right)=0.642(\mathrm{~L} \cdot \mathrm{W})$; where, "L" is the length and "W" is the width $(\mathrm{cm})$ of the leaf. The leaf area on main stems and branches was calculated by the sum of the area of the individual leaves at each one. The total leaf area index (LAItotal, $\mathrm{cm}^{2} \mathrm{~cm}^{-2}$ ) was calculated by summing the individual leaf areas and dividing by the area of soil occupied by a plant, in the same area unit. The leaf area index in the main stems (LAIms, $\mathrm{cm}^{2} \mathrm{~cm}^{-2}$ ) and in the branches (LAIbr, $\mathrm{cm}^{2} \mathrm{~cm}^{2}$ ) of chia plants were also recorded.

The leaf area ratio (LAR, $\mathrm{cm}^{2} \mathrm{~g}^{-1} \mathrm{SDM}$ ) express the ratio between the leaf area (LA, $\mathrm{cm}^{2}$ ), and total shoot dry matter mass (SDM, g) (Equation 4):

$$
L A R=\mathrm{LA} / \mathrm{SDM}
$$

The specific leaf area (SLA, $\left.\mathrm{cm}^{2} \mathrm{~g}^{-1} \mathrm{DML}\right)$ is the ratio between the leaf area $\left(\mathrm{LA}, \mathrm{cm}^{2}\right)$ and the dry matter mass of leaves (DML, g) (Equation 5):

$$
S L A=\mathrm{LA} / \mathrm{DML}
$$

The leaf mass ratio (LMR, $\mathrm{g} \mathrm{g}^{-1}$ ) represents the ratio between the dry matter mass of the leaves (DML, $\mathrm{g}$ ) and the total shoot dry matter mass (SDM, g) (Equation 6):

$$
L M R=\mathrm{DML} / \mathrm{SDM}
$$

Plant height $(\mathrm{cm})$ was measured weekly taking the length between the soil surface and the last visible leaf $(1 \mathrm{~cm}$ of length). Measurements were done in ten plants per plot marked after emergence. The final height was considered when all plants of the plot reached the physiological maturity.

Grain yield was evaluated by collecting the plants of the two central lines of the plots with a total useful area of $2.10 \mathrm{~m}^{2}$. Harvest was done when $80 \%$ of the leaves of each plant exhibited a darker color, indicating that it was dry or dead (Migliavacca et al., 2014). The estimated grain yield was converted to the unit of one hectare.

The $\mathrm{F}$ test was used for the analysis of the variance and, and when this was significant, the comparisons among the means of the treatments were done by the Scott Knott test $(\mathrm{p}>0.05)$. For the analysis, the statistical program SISVAR was used (Ferreira, 2011).

\section{Results and Discussion}

Chia plants were exposed to different conditions of air temperature, photoperiod, solar radiation and rainfall (Figure 1). Air temperature was lower in September, October and early November, reaching highest values in the summer months, and decreasing again in May, June and July, when the lowest air temperatures of the field experiment were recorded (Figure 1a). The absolute minimum and maximum air temperature were $-1.7{ }^{\circ} \mathrm{C}$ $(07 / 19 / 17)$ and $35.1^{\circ} \mathrm{C}(12 / 25 / 16)$, respectively. The photoperiod to which chia plants were exposed ranged from $11.10 \mathrm{~h}(06 / 21 / 2017)$ to $14.96 \mathrm{~h}(12 / 21 / 2016)$. The incident global solar radiation was higher in November, December, January and February (Figure 1b). Rainfall was well distributed during the entire field experiment in a monthly average of $220 \mathrm{~mm}$, what kept the soil water content in adequate levels and favored the plant development without water restrictions. 


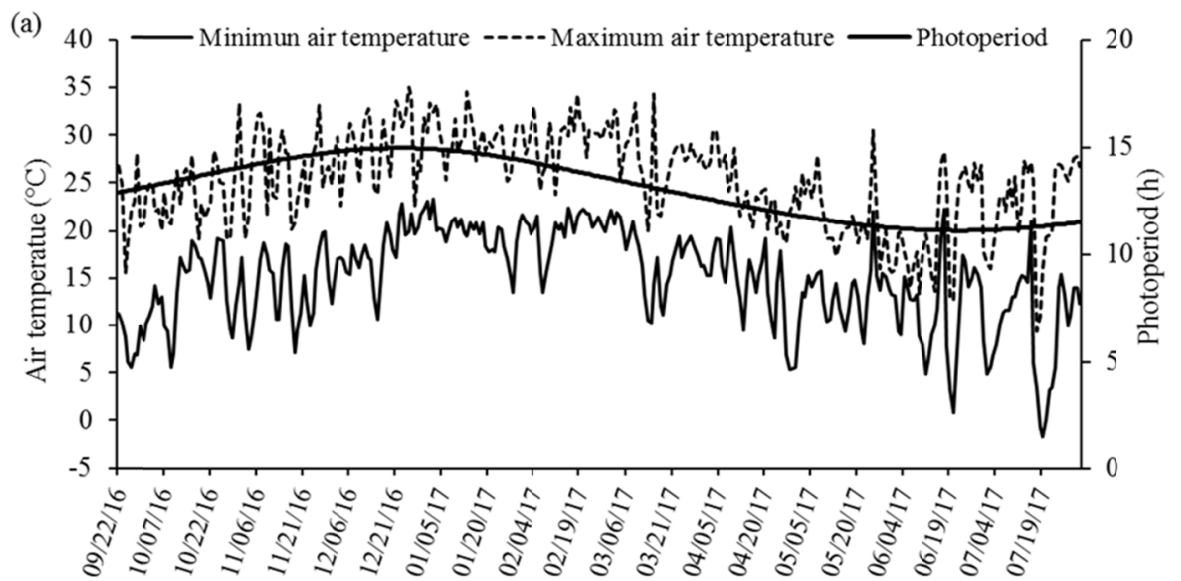

(b)

Date

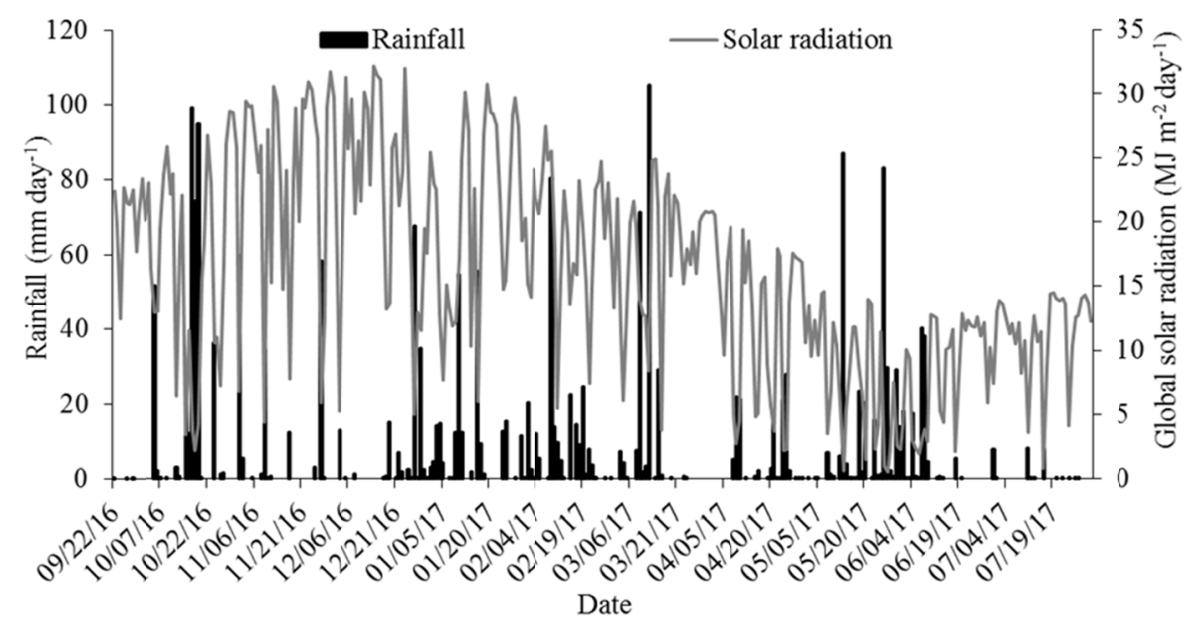

Figure 1. Minimum and maximum daily air temperature $\left({ }^{\circ} \mathrm{C}\right)$ and photoperiod (h) (a), rainfall (mm day $\left.{ }^{-1}\right)$ and incident global solar radiation $\left(\mathrm{MJ} \mathrm{m}^{-2}\right.$ day $^{-1}$ ) (b) between September 2016 and July 2017 in Santa Maria, Rio Grande do Sul State, Brazil

The relative growth rate (RGR) expresses the increase of dry matter mass in relation to the preexisting biomass. In this study, a systematic decrease of RGR along the development cycle was observed for all sowing dates (Figure 2a). Reductions in RGRs throughout the development cycle are generally associated with a decline in the relative plant capacity to produce new biomass (C. P. Peixoto \& M. F. da S. P. Peixoto, 2009) and with a smaller leaf area due to the senescence of leaves. The production of photoassimilates is mostly aimed at the production of non-photosynthetic tissues (stems and roots) and reproductive organs (Zanatta et al., 2016). Until 60 days after emergence (DAE), higher values of RGR were observed in the sowing dates of 02/08/17 and 03/24/17, indicating greater dry matter conversion efficiency in plants sown on these dates. These results, however, were completely reversed from 60 DAE, when plants of early sowing dates reached and maintained the greatest growth rates. It indicates that plants of later sowing dates have a larger mass increment during the vegetative phase, since they need to grow faster as they are rapidly induced to flowering due to crop response to photoperiod. Reductions in RGR of chia plants throughout the development cycle were observed by Zanatta et al. (2016) in an experiment carried out with one sowing date. Similar results were also observed in species such as castor bean (Aires et al., 2011) and rice (Falqueto et al., 2009). 

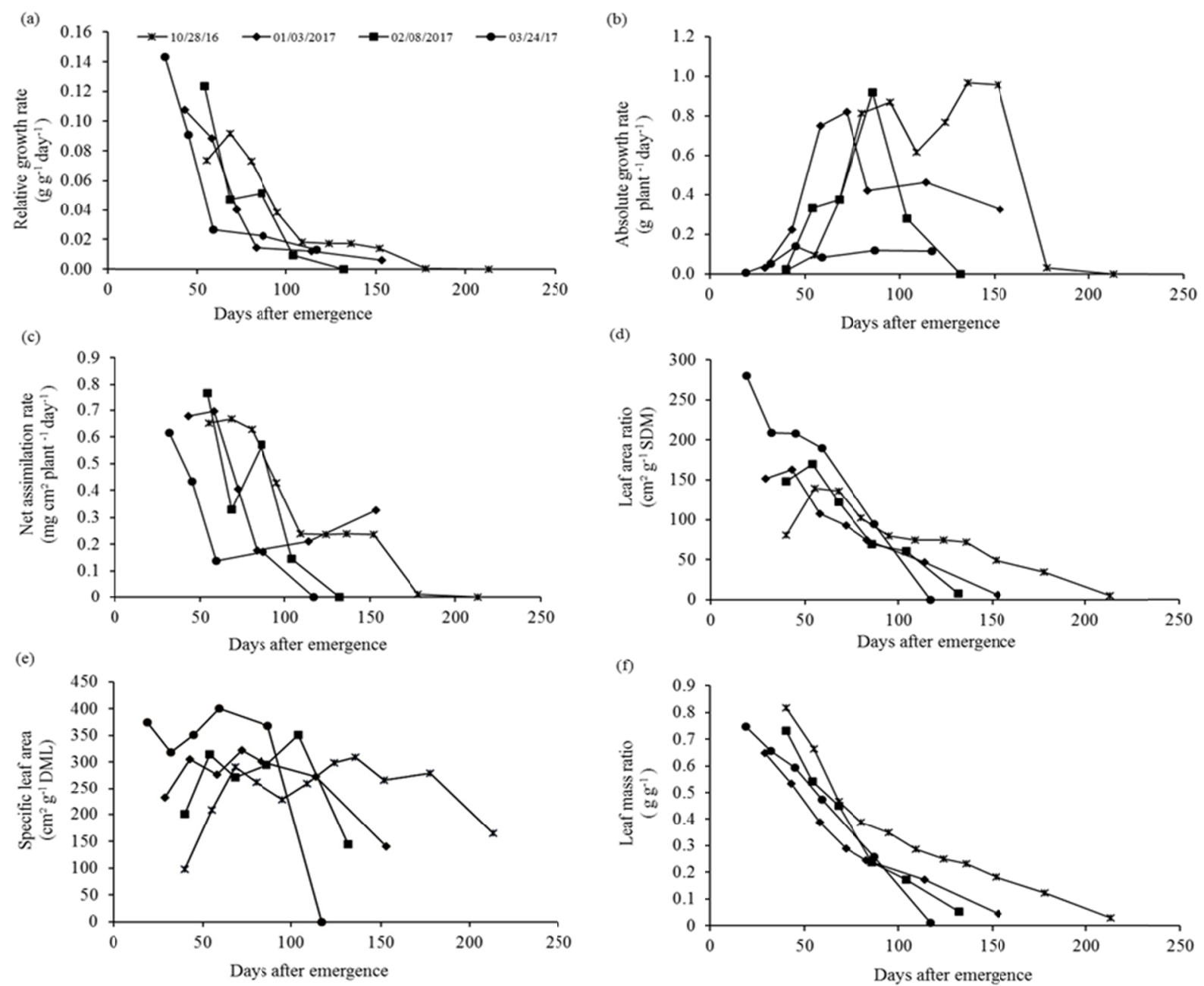

Figure 2. Relative growth rate (RGR, $\left.\mathrm{g} \mathrm{g}^{-1} \mathrm{day}^{-1}\right)(\mathrm{a})$, absolute growth rate (AGR, g plant $\left.{ }^{-1} \mathrm{day}^{-1}\right)(\mathrm{b})$, net assimilation rate (NAR, mg cm${ }^{-2}$ plant $^{-1}$ day $^{-1}$ ) (c), leaf area ratio (LAR, $\left.\mathrm{cm}^{2} \mathrm{~g}^{-1} \mathrm{SDM}\right)(\mathrm{d})$, specific leaf area (SLA, $\left.\mathrm{cm}^{2} \mathrm{~g}^{-1} \mathrm{DML}\right)(\mathrm{e})$, and leaf mass ratio (LMR, $\mathrm{g} \mathrm{g}^{-1}$ ) (f) of chia plants sown at different dates. Santa Maria, Rio Grande do Sul State, Brazil, 2016-2017

According to Benincasa (2004), the absolute growth rate (AGR) indicates the variation or increase of dry matter between two successive samplings, that is, indicates the growth rate $\left(\mathrm{g} \mathrm{day}^{-1}\right)$ over the evaluated period. In the first samplings, there was no significant growth in all sowing dates due to the small size of plants and the reduced number of leaves (Figure 2b). As plant development progresses, AGR increases due to the increasing height and leaf area of plants. It is also observed that plants of the 10/28/16 sowing date presented an AGR superior to the other ones from 110 DAE. These differences were attributed to the size of the plants, which presented a larger leaf area (greater interception of solar radiation) and higher dry matter mass (greater photosynthetic efficiency) as a function of the duration of the vegetative phase (Lima et al., 2007), favoring the greater growth rate on earlier sowings.

Through net assimilation rate (NAR) determinations, it is possible to identify the efficiency of the leaves in the production of new biomass (Figure 2c). This measure expresses the balance between the photosynthesis and the respiration of the plant and describes the efficiency of the net production of the photosynthetic apparatus, or, in other words, the increase of biomass per unit of leaf area and time (Benincasa, 2004; C. P. Peixoto \& M. F. da S. P. Peixoto, 2009). NAR values were higher at the beginning of the crop cycle, in all treatments, because at this stage there were a high number of young leaves at its full assimilatory capacity. Due to the self-shading of leaves, NAR decreased with the increase of LAI and, consequently, with the growth of the plant canopy, since this rate is directly dependent on environmental factors as solar radiation. These results are in agreement with Zanatta et al. (2016) for chia, Ferneda et al. (2016) for soybean and Falqueto et al. (2009) for rice. It is interesting to observe that plants of $01 / 03 / 17$ sowing date had a larger mass increase during the reproductive phase, presenting 
a NAR significantly higher than the other dates (100 DAE). This demonstrates the efficiency in the biomass production capacity at the end of the cycle of these plants, with the same remaining leaf area.

The useful foliar area of a plant is expressed by the leaf area ratio (LAR), a morphophysiological component since it is the ratio between the leaf area (responsible for the light interception and $\mathrm{CO}_{2}$ uptake) and the total dry matter mass of the plan (result of photosynthesis). In other words, it indicates the leaf area that is being used by the plant to produce one gram of dry matter (Benincasa, 2004). The LAR curves showed a rapid increase during the beginning of the vegetative phase (Figure 2d), that is, up to $60 \mathrm{DAE}$, indicating that most of the photosynthesized material is converted into leaves at this phase in order to intercept more sunlight (C. P. Peixoto \& M. F. da S. P. Peixoto, 2009). From this time, LAR decreased due to the age of the plants and the appearance of non-assimilatory tissues and structures, besides the self-shading, senescence and leaf fall (Lima et al., 2007). This pattern was not observed in the sowing of 03/24/2017, in which LAR had decreased since the first evaluation. However, plants of this sowing presented a significantly higher LAR at the beginning of the development cycle, indicating that the smaller plants (smaller leaf area) were less self-shading, with a larger useful leaf area and higher net photosynthesis. These results corroborate with those observed by Gobbi et al. (2001) for Brachiaria decumbens and forage peanut (Arachis pintoi), which presented changes in the specific leaf area and quantitative foliar anatomy when submitted to shading conditions.

The leaf area ratio can be separated into two components: specific leaf area (SLA) and leaf mass ratio (LMR). The SLA is the anatomical (morphological) component while the LMR (leaf dry matter mass/shoot dry matter mass of the plant) is basically physiological (Benincasa, 2004). The specific leaf area (Figure 2e) was very similar throughout the development of the plants in all sowing dates, with low values in the first evaluation and later increases at the beginning of the crop cycle. SLA was decreasing with plant development, similar to the decreases observed by Falqueto et al. (2009) for rice. The low SLA values of the first evaluation disagree with Benincasa (2004), who states that at the beginning of crop development the SLA may be higher, indicating that the leaves are thin and with low dry matter mass and area. However, in our study, there was a great increase in leaf area after the first evaluation and leaves were not very thick (the increase in SDM does not follow the increase in LA), which explains the higher values of SLA in the second evaluation.

According to Falqueto et al. (2009), reductions in SLA throughout the crop cycle are related to the translocation of leaf carbohydrate reserves to other parts of the plant, especially to the stems and to reproductive structures, a behavior also observed by Gobbi et al. (2011) on Brachiaria decumbens and forage peanut under shading conditions. For Alvarez et al. (2012), SLA represents the differences in leaf thickening, that is, it allows verifying if plants are accumulating photoassimilates in their leaves or translocating them to other organs.

There was also a decrease in LMR (Figure 2f) with the development of the plants in all sowing dates studied. The higher values of LMR at the beginning of the cycle reflect higher allocation of assimilates to leaves growth, considered as a preferential metabolic drain (Falqueto et al., 2009). From this period, LMR values were reduced with plant ontogeny. Such reduction observed throughout the crop cycle was consistent with the results described by Falqueto et al. (2009), and reflects the mobilization of photoassimilated compounds to other plant organs. Plants of 10/28/16 sowing date presented the highest LMR values during the entire cycle. At this sowing date, due to the greater plant growth, the photosynthetic production was invested largely in the dry matter constitution of leaves.

The temporal evolution of the total leaf area of chia plants in all sowing dates is shown in Figure 3a. Plants presented a reduction in the maximum leaf area index (LAImax) with the delay of the sowing date. The mean LAImax of chia plants was 12.79 on $09 / 22 / 16,13.08$ on $10 / 28 / 16,7.10$ on $01 / 03 / 17,5.64$ on $02 / 08 / 17$, and 2.06 on $03 / 24 / 17$. The LAImax reduction occurred due to the shortening of the crop cycle with the sowing delay, which can be explained by the fact that chia is a short-day plant (Jamboonsri et al., 2012). Late sowings occurred when the day length was decreasing, and the plants were induced earlier to flowering, causing the acceleration of the cycle. Similar results were found by Zanon et al. (2015b), who observed that with the delay of the sowing date soybean cultivars were induced to flowering earlier and reduced the LAImax. Plants sown on 09/22/16 and 10/28/16 presented high LAImax, which made them susceptible to lodging during high wind speed events in Santa Maria, mainly in the months of January and February, which reached $80 \mathrm{~km} \mathrm{~h}^{-1}$ (data obtained from the automatic weather station belonging to the 8th DISME/INMET). Therefore, these sowing dates are not recommended due to the longer duration of the vegetative phase, which results in an excessive growth of the plants. The same was observed by Amorim et al. (2011), which identified a direct relationship between early sowing dates and higher soybean plant growth with lodging. 

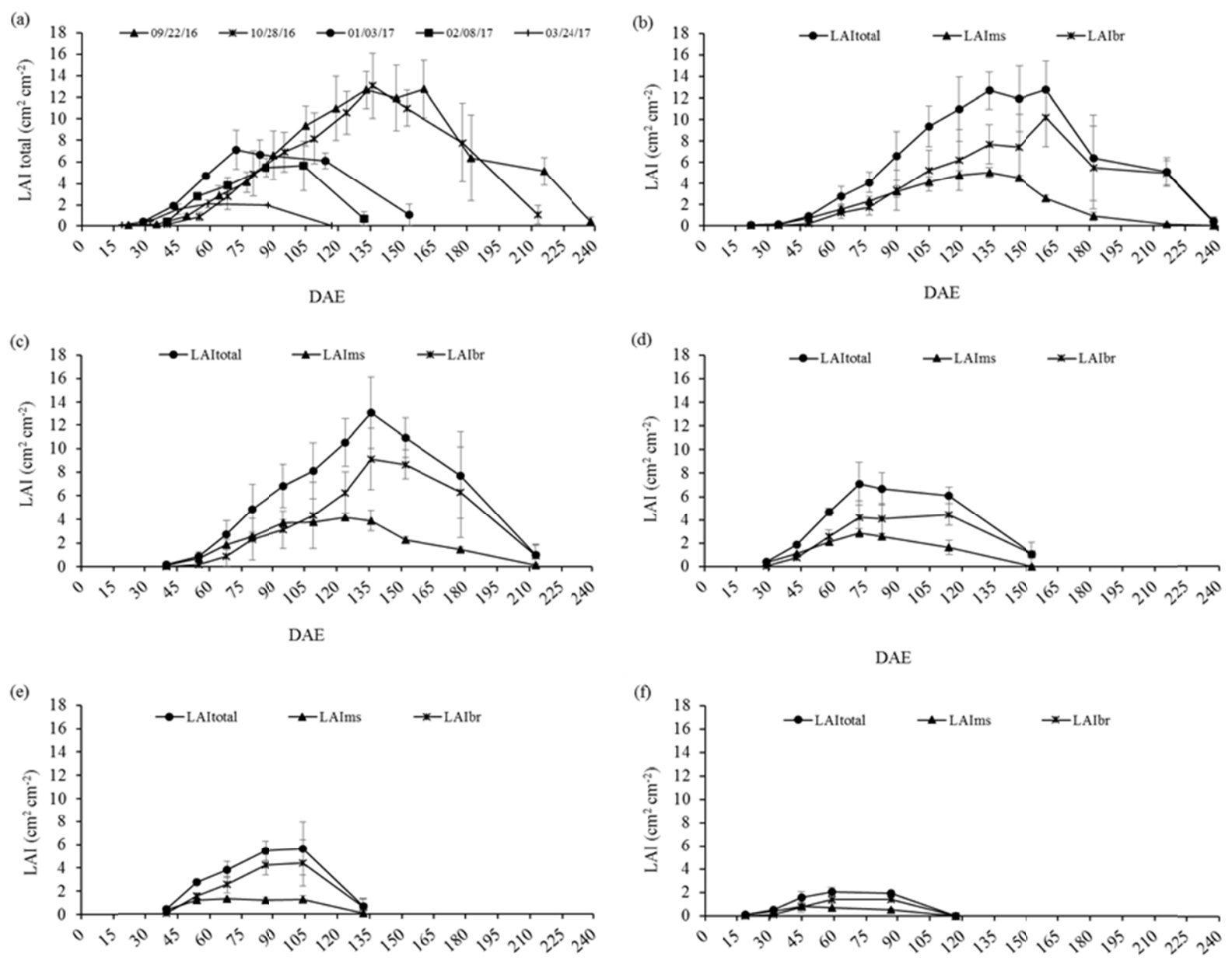

DAE

DAE

Figure 3. Temporal evolution of the total leaf area index (LAItotal, $\mathrm{cm}^{2} \mathrm{~cm}^{-2}$ ) of chia plants in all sowing dates (a), and the temporal evolution of the total leaf area index (LAItotal, $\mathrm{cm}^{2} \mathrm{~cm}^{-2}$ ), the leaf area index in the main stem (LAIms, $\mathrm{cm}^{2} \mathrm{~cm}^{-2}$ ) and in branches (LAIbr, $\mathrm{cm}^{2} \mathrm{~cm}^{-2}$ ) in the sowing dates of 09/22/16 (b), 10/28/16 (c),

01/03/17 (d), 02/08/17 (e), and 03/24/17 (f). Santa Maria, Rio Grande do Sul State, Brazil, 2016-2017

The evolution of the total leaf area index (LAItotal), the leaf area index of the main stem (LAIms) and the leaf area index of branches (LAIbr) is presented in Figures 3b (09/22/2016), 3c (10/28/2016), 3d (01/03/17), 3e (02/08/17) and $3 \mathrm{f}(03 / 24 / 2017)$. Regardless of the sowing date, the leaf area contribution of the branches to the LAItotal started when the plants had around 4 to 6 leaves on the main stem. Working with soybean, Zanon et al. (2015b) verified that branching started when the plants were between stages V3 and V5.

In general, the number and the contribution of the branches in LAI increased with the development of the plants in all sowing dates. At the sowings of September, the LAIbr contribution increased from $0.11 \%$ at the beginning of the vegetative phase to $86.10 \%$ at the beginning of flowering. This contribution in the same phases increased from $17.51 \%$ to $79.43 \%$ at November sowing date and from $12.23 \%$ to $61.64 \%$ in January sowing date. For chia plants sown in February and March, this contribution rose from $16.31 \%$ to $77.86 \%$ and from $0.71 \%$ to $67.11 \%$, respectively. At the beginning of the crop cycle, chia plants are very small and practically do not produce branches, so the contribution to the LAItotal is practically only of the main stem. As the cycle progresses, the plants intensify the production of branches and produce many leaves in these parts, which favors the contribution of LAlbr to LAItotal. This is a typical characteristic of the chia crop which has to produce a much higher number of branches as the sowing date is anticipated.

The number of branches and the contribution of the branches to LAI decreased with the delay of the sowing date. The lower contribution of LAIbr in late sowings is associated with the shortening of the development cycle and the reduction of the number of branches. These results corroborate with Zanon et al. (2015b), which also found a 
decrease in the contribution of the branches with the delay of the sowing date of soybean, which is a crop responsive to photoperiod and a short-day species, as well as chia.

The mean variation of the total dry matter accumulated in chia plants at different sowing dates is presented in Figure 4a. Plants sown at 10/28/2016 accumulated more dry matter in relation to the other sowing dates in which there are sharp falls in accumulation. It can be attributed to the difference in the duration of the vegetative phase between the plants of the early sowings when compared to the late sowings. Plants of 10/28/2016 sowing date presented 137 days of vegetative phase, while the vegetative phase of plants sown on 03/24/2017 lasted 35 days. The shorter duration of the vegetative phase of the plants of 03/24/17 sowing date implied a lower accumulation of SDM due to the shorter plant growth period. This result is consistent with those observed in short-day species such as soybean (Cruz et al., 2010; Zanon et al., 2015a).
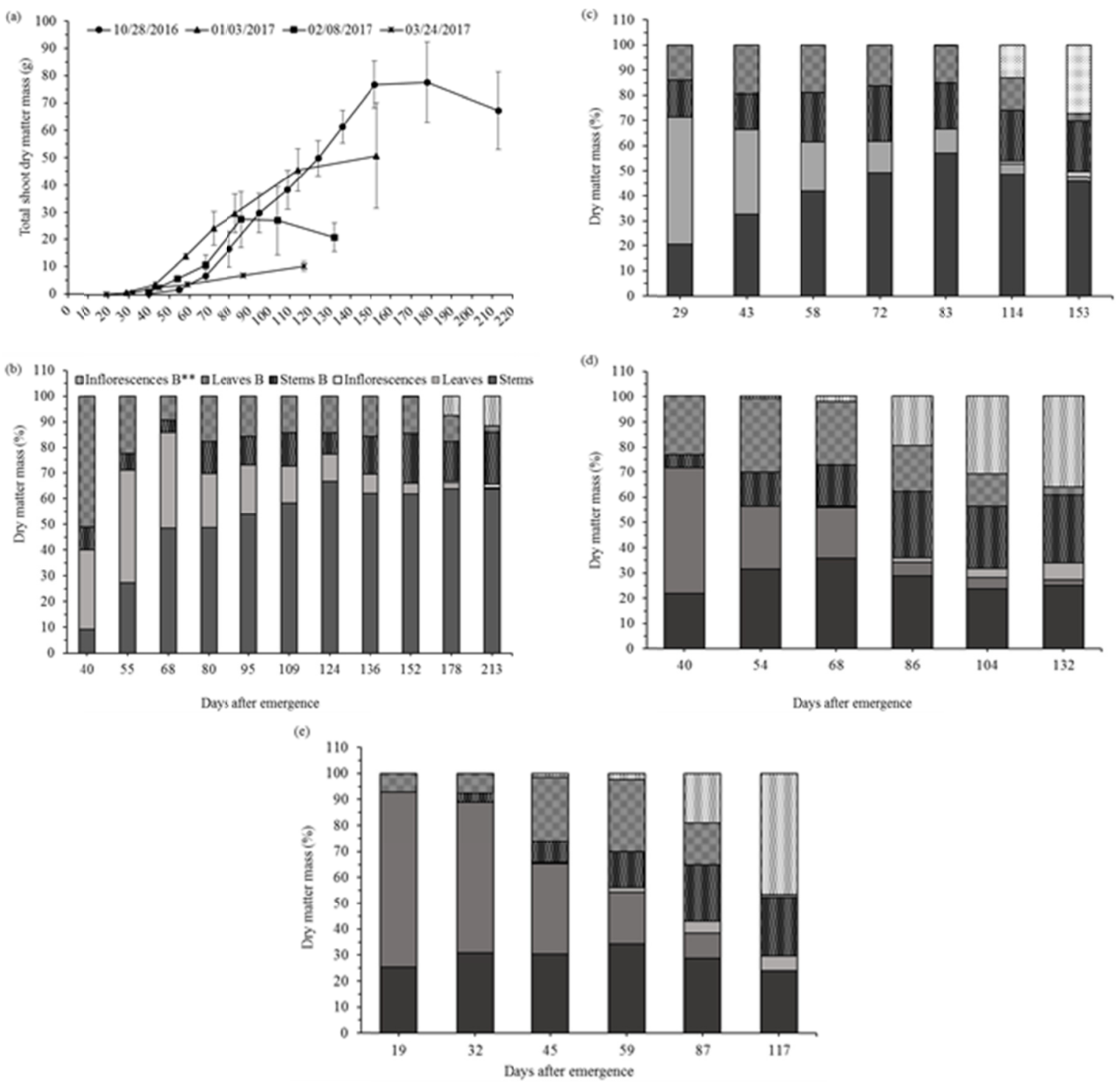

Figure 4. Total shoot dry matter mass (g) of chia plants in all sowing dates (a), the dry matter mass (g) of each plant part (stems, leaves and inflorescences) in the main stems (solid-filled columns) and in branches (texture-filled columns) in the dates of 10/28/16 (b), 01/03/17 (c), 02/08/17 (d), 03/24/17 (e) of chia plants in all sowing dates. ${ }^{*} \mathrm{~B}=$ branches

The dry matter accumulation in the early plant stages was low because plants were small and have few leaves, and there is similarity between plants of all sowing dates in this period (30 to 45 DAE). From 45 DAE on, dry matter accumulation of the early sowing dates (10/28/16 and 01/03/17) differed from the late sowing dates 
(02/08/17 and 03/24/17). This trend was also observed in Cruz et al. (2010) who verified that the accumulation rate of dry matter and nutrients in soybeans in the initial development phase was low, increasing progressively over time and reaching the maximum between flowering and the beginning of grain filling.

Regarding the partition of the total shoot dry matter (SDM) between the different plant parts (stems, leaves and inflorescences), plant growth implied on a higher SDM accumulation in stems and an accumulation decrease in leaves in all sowing dates studied: 10/28/16 (Figure 4b), 01/03/17 (Figure 4c), 02/08/17 (Figure 4d) and 03/24/17 (Figure 4e). From the beginning of flowering, there was also production of inflorescences and increase of dry matter accumulation in the reproductive structures. Concerning the dry matter divided between main stems and branches, it is possible to observe that during the entire period the main stem represented between 60 and $70 \%$ of the accumulated SDM for the early sowing dates, and between 40 and $50 \%$ for late sowing. The early sowings produced higher plants and the main stem had the largest matter to support the plant. In late sowing, the size of the plants was smaller and the mass of the branches, mainly after flowering, was higher due to the greater number and mass of inflorescences in these structures. Chia plants sown at 10/28/16, 01/03/17 and 02/80/17 were the most productive (Figure 5a), not statistically differing from each other. However, the grain yield analyzed in absolute numbers were higher in the sowing of 01/03/17 with a final production of $2,041 \mathrm{~kg}$ ha- 1 . It is important to emphasize that the plants of $10 / 28 / 16$ sowing date, being an early sowing and providing the highest plant growth, were susceptible to lodging. Besides, because the plants stayed more time in the field, they were more susceptible to diseases and pests, what does not make this sowing date indicated in terms of production costs even with the high yield. It indicated that very early or late sowings have a reduction in grain yield, and the adequacy of sowing date is paramount for achieving high yields. The results presented corroborate with the results observed by Jiang et al. (2011) and Meotti et al. (2012), which pointed out that plants with excessive growth and high leaf area index from early sowings are susceptible to lodging and grain yield reduction, as well as plants with reduced high and few branches from late sowings have a lower yield and expression of grain yield characteristics. Excessive plant growth may also affect the physical and physiological quality of chia grains as observed by Goergen et al. (2018).
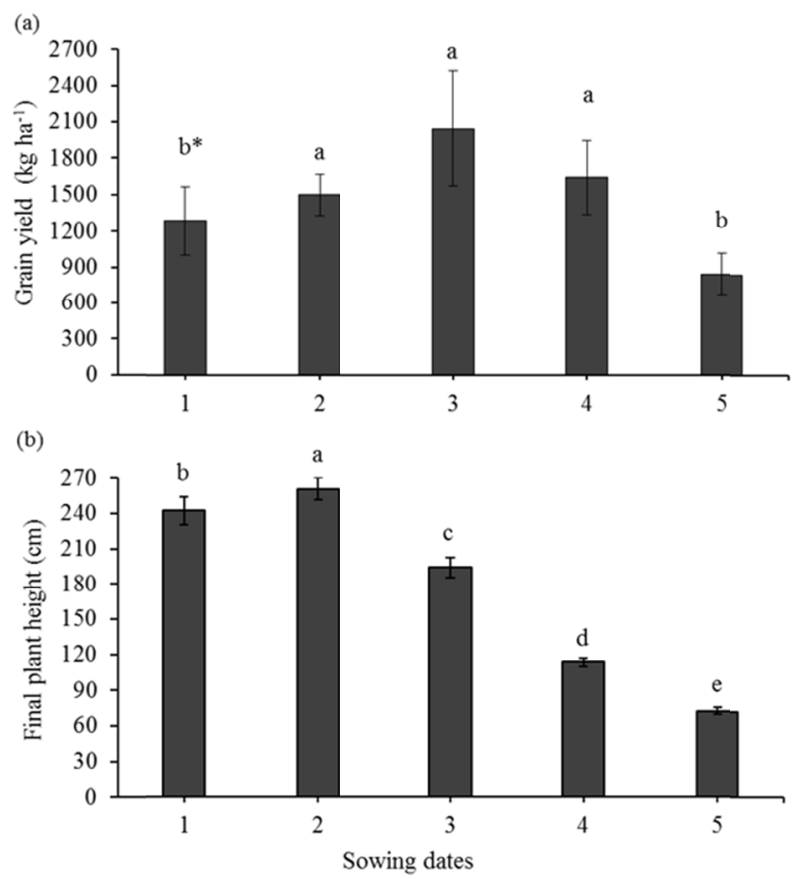

Figure 5. Grain yield $\left(\mathrm{kg} \mathrm{h}^{-1}\right)$ (a) and final plant height $(\mathrm{FPH}, \mathrm{cm})(\mathrm{b})$ of chia sown at different sowing dates: 1 (09/22/16), $2(10 / 28 / 16), 3(01 / 03 / 17), 4(02 / 08 / 17)$, and $5(03 / 24 / 17)$. *Means followed by the same uppercase letter do no significantly differ by the Scott Knott test at $5 \%$ probability. Santa Maria, Rio Grande do Sul State, Brazil, 2016-2017

Plants of the $01 / 03 / 17$ sowing date, although being the most productive, accumulated less solar radiation (MJ $\mathrm{m}^{-2}$ ) during their development cycle when compared to sowings of $09 / 22 / 16$ and $10 / 28 / 16$. While the sowing of 09/22/16 and 10/28/16 accumulated 4,281 and 3,679 $\mathrm{MJ} \mathrm{m}^{-2}$, respectively, sowing of 01/03/17 accumulated 
2,281 $\mathrm{MJ} \mathrm{m}^{-2}$. It means that a greater accumulation of solar radiation will not necessarily result in higher grain yield, because not all the energy available to the plants is used in the photosynthesis process, and because the net photosynthesis depends on the energy expended by the plant with the respiration and maintenance of the vegetative and reproductive organs, and the high productivity of a crop depends also on other biotic and abiotic factors, such as water availability, soil fertility, pests incidence, diseases and invasive plants.

The average grain yield of chia plants under less technified conditions is around 500 to $600 \mathrm{~kg} \mathrm{ha}^{-1}$. However, some farmers obtained yields of up to $1,200 \mathrm{~kg} \mathrm{ha}^{-1}$. In some studies in Argentina under high fertilization and adequate irrigation conditions, yields of $2,500 \mathrm{~kg} \mathrm{ha}^{-1}$ were reached (Coates, 2011), similar to those reached in this study in the sowing dates that provide the best meteorological conditions, mainly a photoperiod for an appropriate growth.

When comparing the height of chia plants at different sowing dates (Figure $5 b$ ), there was variation in the final height of the plants (FPH). Plants of sowing date 2 (10/28/2016) were higher, differing from the plants of the sowings $1(09 / 22 / 16) ; 3(01 / 03 / 2017) ; 4(02 / 08 / 2017)$ and $5(03 / 24 / 17)$, which were lower.

The higher chia plants in sowings $1(09 / 22 / 16)$ and $2(10 / 28 / 16)$ were the result of the longer duration of the vegetative phase (178 and 137 days, respectively), which provided the greatest growth. Plants of sowings 3,4 and, mainly, 5 reached a lower FPH because the vegetative phase was shorter ( 75,50 and 35 days, respectively) due to days with smaller photoperiod.

It was also observed, in the field conditions, that at the beginning of the vegetative phase the plants of sowing dates 1 and 2 had a slower growth, due to the lower air temperature and availability of solar radiation (Figures 1 and 2), when compared to availability of these meteorological elements and the growth rate, mainly in the sowing dates 4 and 5 .

The differences in FPH of chia at different sowing dates are due to the fact that this species has its growth and development regulated by air temperature and photoperiod. The response to the photoperiod is the main factor that explains the longer duration of the vegetative phase in the early sowing, which provides higher plants and, on the contrary, a shorter duration of the vegetative phase in late sowing, which results in shorter plants. The results are consistent with those observed in short-day species such as soybean (Jiang et al., 2011; Meotti et al., 2012; Zanon et al., 2015a), and corroborate with the results of Win et al. (2018) for the cultivation of chia in China.

As the chia crop is a short day plant, if it is cultivated anywhere in the world with latitudes different than $0^{\circ}$, its growth and development characteristics will be the same as the ones observed in this work: excessive plant growth, greater height and leaf area in early sowings. The greater latitude, the more expressive this behavior will be, because the photoperiod at that time would be larger than the inductive crop photoperiod.

\section{Conclusion}

Physiological indexes indicated that there is greater plant growth at earlier sowing dates, either in shoot dry matter mass, plant height and leaf area index.

The leaf area index of branches is progressively increased with plant development and contributes significantly to total leaf area index of chia plants in all studied sowing dates.

The main stem represents between 60 and $70 \%$ of the shoot dry matter accumulated in the early sowing dates, and between 40 and $50 \%$ in late sowing.

The best sowing date in terms of grain yield is $01 / 03 / 17$.

\section{References}

Aires, R. F., Silva, S. D. A., \& Eicholz, E. D. (2011). Análise de crescimento de mamona semeada em diferentes épocas. Ciência Rural, 41(8), 1347-1353. https://doi.org/10.1590/S0103-84782011005000109

Alvarez, R. C. F., Crusciol, C. A. C., Nascente, A. S., Rodrigues, J. D., \& Habermann, G. (2012). Gas exchange rates, plant height, yield components, and productivity of upland rice as affected by plant regulators. Pesquisa Agropecuária Brasileira, 47(10), 1455-1461. https://doi.org/10.1590/S0100-204X2012001000007

Alvares, C. A., Stape, J. L., Sentelhas, P. C., de Moraes, G., Leonardo, J., \& Sparovek, G. (2013). Köppen’s climate classification map for Brazil. Meteorologische Zeitschrift, 22(6), 711-728. https://doi.org/10.1127/ 0941-2948/2013/0507 
Amorim, F. A., Hamawaki, O. T., Sousa, L. B., Lana, R. M. Q., \& Hamawaki, C. D. L. (2011). Época de semeadura no Potencial produtivo de Soja em Uberlândia-MG. Semina: Ciências Agrárias, 32(1), 1793-1802. https://doi.org/10.5433/1679-0359.2011v32n4Sup1p1793

Antoniazzi, N., \& Deschamps, C. (2006). Análise de crescimento de duas cultivares de cevada após tratamentos com elicitores e fungicidas. Ciência Rural, 36(4), 1065-1071. https://doi.org/10.1590/S0103-847820 06000400004

Benincasa, M. P. (2004). Análise de Crescimento de Plantas (noções básicas). Jaboticabal: Funep.

Coates, W. (2011). Whole and Ground Chia (Salvia hispanica L.) Seeds, Chia Oil-Effects on Plasma Lipids and Fatty Acids. In V. R. Preedy, R. R. Watson, \& V. B. Patel (Eds.), Nuts and Seeds in Health and Disease Prevention (pp. 309-315). San Diego: Academic Press. https://doi.org/10.1016/B978-0-12-375688-6. 10037-4

Cruz, T. V., Peixoto, C. P., \& Martins, M. C. (2010). Crescimento e produtividade de soja em diferentes épocas de Semeadura no oeste da Bahia. Scientia Agraria, 11(1), 33-42. https://doi.org/10.5380/rsa.v11i1.15941

Falqueto, A. R., Cassol, D., Magalhães Júnior, A. M., Oliveira, A. C., \& Bacarin, M. A. (2009). Partição de assimilados em cultivares de arroz diferindo no potencial de produtividade de grãos. Bragantia, 68(3), 453-461. https://doi.org/10.1590/S0006-87052009000300002

Ferneda, B. G., Boeing, E., Silva, A. C., Souza, A. P., Silva, S. G., Martim, C. C., ... Tanaka, A. A. (2016). Graus-dias na estimativa das taxas de crescimento de quatro cultivares de soja em diferentes épocas de plantio. Nativa, 4(3), 121-127. https://doi.org/10.14583/2318-7670.v04n03a01

Ferreira, D. F. (2011). Sisvar: A computer statistical analysis system. Ciência e Agrotecnologia, 35(6), 1039-1042. https://doi.org/10.1590/S1413-70542011000600001

Gobbi, K. F., Garcia, R., Ventrella, M. C., Neto, A. F. G., \& Rocha, G. C. (2011). Área foliar específica e anatomia foliar quantitativa do capim-braquiária e do amendoim-forrageiro submetidos a sombreamento. Revista Brasileira de Zootecnia, 40(7), 1436-1444. https://doi.org/10.1590/S1516-35982011000700006

Goergen, P. C. H., Nunes, U. R., Stefanello, R., Lago, I., Nunes, A. R., \& Durigon, A. (2018). Yield and Physical and Physiological Quality of Salvia hispanica L. Seeds Grown at Different Sowing Dates. Journal of Agricultural Science, 10(8), 182-191. https://doi.org/10.5539/jas.v10n8p182

Jamboonsri, W., Phillips, T. D., Geneve, R. L., Cahill, J. P., \& Hildebrand, D. F. (2012). Extending the range of an ancient crop, Salvia hispanica L.-A new $\omega 3$ source. Genetic Resources and Crop Evolution, 59(2), 171-178. https://doi.org/10.1007/s10722-011-9673-X

Jiang, Y., Yan, W., Ahn, J. K., \& Chung, I. M. (2011). Long-day effects on the terminal inflorescence development of a photoperiod sensitive soybean [Glycine max (L.) Merr.] variety. Plant Science, 180(3), 504-510. https://doi.org/10.1016/j.plantsci.2010.11.006

Lima, J. F., Peixoto, C. P., \& Ledo, C. A. S. (2007). Índices fisiológicos e crescimento inicial de mamoeiro (Carica papaya L.) em casa de vegetação. Ciência e Agrotecnologia, 31(5), 1358-1363. https://doi.org/ 10.1590/S1413-70542007000500013

Meotti, G. V., Benin, G., Silva, R. R., Beche, E., \& Munaro, L. B. (2012). Épocas de semeadura e desempenho agronômico de cultivares de soja. Pesquisa Agropecuária Brasileira, 47(1), 14-21. https://doi.org/10.1590/ S0100-204X2012000100003

Migliavacca, R. A., Silva, T. R. B., Vasconcelos, A. L. S., Filho, W. M., \& Baptistella, J. L. C. (2014). O cultivo da chia no Brasil: futuro e perspectivas. Journal of Agronomic Sciences, 3, 161-179.

Peixoto, C. P., \& Peixoto, M. F. da S. P. (2009). Dinâmica do crescimento vegetal. In C. A. L. Carvalho, A. C. V. L. Dantas, F. A. de C. Pereira, A. C. F. Soares, J. F. Melo Filho, \& G. J. C. Oliveira (Eds.), Tópicos em ciências Agrárias (pp. 39-53). Universidade Federal do Recôncavo da Bahia.

Usda. (1999). Soil taxonomy. A basic system of soil classification for making and interpreting soil surveys. Washington: USDA.

Win, A. N., Xue, Y., Chen, B., Liao, F., Chen, F., Yin, N., ... Chai, Y. (2018). Chia (Salvia hispanica) experiment at a $30^{\circ} \mathrm{N}$ site in Sichuan Basin, China. Ciência Rural, 48(9), e20180105. https://doi.org/ $10.1590 / 0103-8478 \mathrm{cr} 20180105$ 
Zanatta, T. P., Libera, D. D., Silva, V. R., Werner, C. J., \& Zanatta, M. M. (2016). Análise do crescimento da cultura da chia (Salvia hispanica). Revista Cultivando o Saber, 9(3), 377-390.

Zanon, A. J., Streck, N. A., Rocha, T. S. M., Alberto, C. M., Bartz, A. C., Paula, G. M., ... Bexaira, K. P. (2016). Efeito do tipo de crescimento no desenvolvimento de cultivares modernas de soja após o início do florescimento no Rio Grande do Sul. Bragantia, 75(4), 445-458. https://doi.org/10.1590/1678-4499.535

Zanon, A. J., Winck, J. E. M., Streck, N. A., Rocha, T. S. M., Cera, J. C., Richter, G. L., ...Marchesan, E. (2015a). Desenvolvimento de cultivares de soja em função do grupo de maturação e tipo de crescimento em terras altas e terras baixas. Bragantia, 74(4), 400-411. https://doi.org/10.1590/1678-4499.0043

Zanon, A. J., Streck, N. A., Richter, G. L., Becker, C. C., Rocha, T. S. M., Cera, J. C., ...Weber, P. S. (2015b). Contribuição das ramificações e a evolução do índice de área foliar em cultivares modernas de soja. Bragantia, 74(3), 279-290. https://doi.org/10.1590/1678-4499.0463

\section{Copyrights}

Copyright for this article is retained by the author(s), with first publication rights granted to the journal.

This is an open-access article distributed under the terms and conditions of the Creative Commons Attribution license (http://creativecommons.org/licenses/by/4.0/). 